\title{
事務所の内装に使われた木材によってもたらされる視覚的影響 聞き取り調査の多次元尺度構成法による解析*1
}

\author{
末吉修三*2, 森川 岳*2 \\ Visual Influence of Wood Used in Workplace Interiors \\ Multidimensional scaling analysis by individual interviews*1
}

Shuzo Sueyoshi*2 and Takeshi MoRIKAwA*2

\begin{abstract}
This study investigated the visual influence of wood used in workplace interiors through a quantitative analysis of textual data obtained by interviews using photographs of workplace interiors. Twenty photographs of workplace interiors were presented to each participant, who was requested to divide them into groups on the basis of similar impressions. Subsequently, the participant was asked his or her impression of the companies in each group and the reason for such an impression. Nonmetric multidimensional scaling analysis was conducted on the grouped photographs and corresponding answers. Although the participants had not been informed that the photographs were of "wood interiors" and "non-wood interiors," the photographs were divided into "wood interior" and "non-wood interior" ones in two-dimensional space, and also the "wood interior" ones were placed around the word "wood." The words "warm," "comfortable," "calm," "bright" and "friendly," which are related to a good workplace environment and good impressions of companies and workers, were also placed around the word "wood." This suggested that wood used in workplace interiors would have a favorable effect on the people there.
\end{abstract}

Keywords : visual influence, wood interior, workplace, multidimensional scaling, interviews.

事務所の内装写真を用いた聞き取り調査で得られたテキスト型データの計量的分析に基づい て，事務所の内装に使われた木材がもたらす視覚的影響を検討した。被験者に対して20枚の事務 所内装写真を提示し，類似の印象を持つグループに分けさせた後，グループごとにその会社の印 象およびそのような印象を持つ理由を尋ねた。グループに分けられた写真および聞き取った回答 について, 非計量的多次元尺度構成法による解析を行った。被験者には, 写真に木質と非木質の 内装が含まれることを説明していないにも関わらず, 2 次元空間に木質内装と非木質内装の写真 が分かれて位置付けられ，木質内装写真は「木材」の近くに位置付けられた。その「木材」の周 辺に「あたたかい」，「快適」，「静か」，「明るい」，「友好的」など良好な事務所環境あるいはその 会社や社員に対する好印象につながる語が位置付けられ，事務所の内装で木材が好ましい視覚的 影響をもたらすことが示唆された。

\footnotetext{
*1 Received May 11, 2016 ; accepted June 24, 2016.

*2 森林総合研究所 Forestry and Forest Products Research Institute, Tsukuba 305-8687, Japan

Corresponding author: S. Sueyoshi (sue@ffpri.affrc.go.jp)
} 


\section{1. 緒言}

公共建築物などの大規模建築物の木質内装化を推 進する上で，木材が居住環境で果たす役割を明らか にすることは重要な課題である。その中でも，多く の人々が活動する事務所で，木材が人の五感に与え る影響を明らかにする意義は大きい。

ところで，五感の中で視覚を通じて得られる情報 は, 人が感覚器官を通じて外界から受ける情報の 83\% と言われている1)。このように情報伝達手段と して重要な役割を担っている視覚と木材の関わりに ついては, 仲村が視覚刺激としての木材に関連する 研究を概説している2)。それらの中で, 内装画像の 印象評価に関する研究では,「あたたかい」や「自 然な」印象は, 内装に現れている木材の色相や木材 量と関わりが深いことが明らかにされている3.4)。 また，全内装面に占める木材の面積比率，いわゆる 木材率が目測で見積もられることが明らかにされて いる5)。コンピュータグラフィックスで表現された 住宅内装画像を用いた実験では，木材率を主観申告 させ，木材量判断の恒常性を示す結果が得られてい $ろ^{6)}$ 。臨場感を重視して, 実大規模の実験も行われ ている。例えば，カラマツ内装材の印象に対する照 明の影響7) やヒノキ壁面と鋼板壁面とで被験者への 生理的抒よび心理的影響が異なること鼻 が示されて いる。また, 広さや調度品が同じで木材率の異なる 部屋あるいは天井と壁に造作の梁や柱を配した部屋 に被験者を誘導し, 血圧, 心拍, 脳血液動態などの 生理応答の測定㧍よび部屋の印象評価などを行うこ とによって，木材率や梁・柱の視覚刺激が人に及ぼ す影響が明らかにされている ${ }^{9-11)}$ 。

事務所の内装については，木材をあらわしにする ことがその事務所の使用者の第一印象を好ましいも のにすること ${ }^{12)}$ ，あるいは木材が多用された職場を 提供する組織は働く場として圧倒的に好ましいと評 価されること ${ }^{13)}$ が報告されている。筆者らは, こ れらの事務所内装に関する研究を進めていた研究グ ループと共同で, 戸建住宅の外装や事務所の内装に 関する調查研究を実施した。その中で, 戸建住宅の 工法と外装から受ける居住者への印象について, 大 学生を対象にして集団で一斉のアンケート調査を実 施した結果, 住宅の工法や外装によって居住者の成 熟度・対人関係・自信に関わる印象が変わることが 明らかになった ${ }^{14)}$ 。また, 事務所内装に木材が使わ れることによる人への影響を視覚に基づく主観評価 によって明らかにするため, 大学生を被験者として 個別に事務所の内装写真を提示し, 類似の印象を持
つグループに分けさせた後, 各グループの印象を聞 き取った。被験者ごとにグループに番号を割り当て, その番号を付けた写真を対象として多次元尺度構成 法による解析およびクラスター解析を行った結果, 木質内装と非木質内装の写真にほほ分けられるこ と, ならびに被験者が事務所内装写真から受ける印 象を分析した結果，木質の事務所内装写真は抒抒む ね好ましい印象を与えることがそれぞれわかっ $た^{15)}$ 。

本研究では, 既報 ${ }^{15)}$ の聞き取り調査で得られた すべてのデー夕を計量的に分析し，事務所の内装に 使われた木材によってもたらされる視覚的影響を検 討した結果を報告する。

\section{2. 実験}

\section{1 被験者}

筑波大学の学生 28 名（男子 12 名, 女子 16 名) が, 被験者として参加した。被験者の年齢は, 25才から 34 才に入る 1 名を除いて18才から 24 才で, 全員日本 人であった。所属は 11 の専攻に渡り, 理系 23 名, 文 系 5 名であった。出身地は, 中国の上海 1 名を除き, 北海道から大分県まで19の都道府県に及んだ。

\section{2 個別面接による聞き取り調査}

試験者は机を隔てて対面する被験者に対して，本 調查の目的が事務所の内装デザインに関する主観評 価であることを説明し，とくに木材に関心があるこ とを意識させないようにした。続いて, 実験手順を 以下のように説明した。1) 次の個人情報を尋ねる。
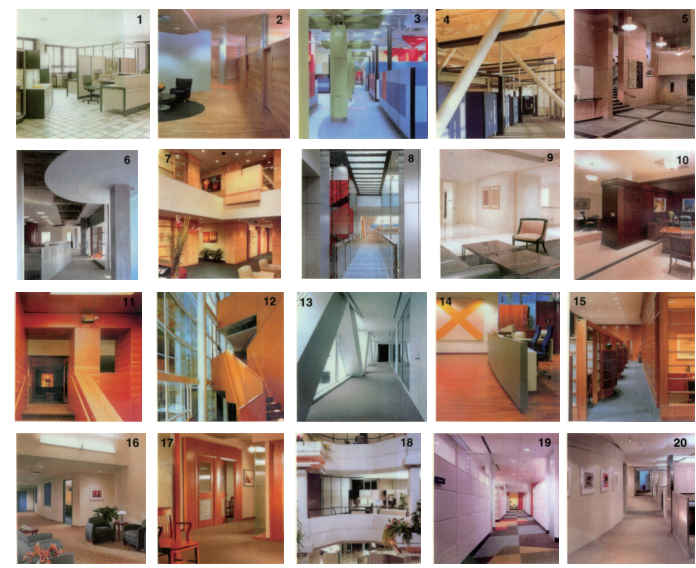

Fig. 1. Photographs of workplace interiors.

Note: Photos 2, 7, 10, 11, 12, 14, 15 and 17 show wood workplace interiors. Photos $1,3,4,5,6,8,9,13$, $16,18,19$ and 20 show non-wood workplace interiors. This figure appeared in reference No. 15. 
(1)性別, (2)年齢, (3)所属 (学部, 理系·文系), (4) 出生地 / 出生県 (都市・郊外・地方 / 都道府県), (5)生育地 / 生育県 (都市・郊外・地方 / 都道府県), (6)実家の建物種別（高層マンション，低層マンショ ン, 連続住宅, 戸建住宅)。2）提示された事務所 内装写真（たて約 $4.8 \mathrm{~cm}$, よこ約 $4.6 \mathrm{~cm}$ ) 20枚を類 似の印象を与えるグループに分ける。その際, グル ープの個数に制限はない。3)各グループについて, 次の二つの質問をする。

質問 1 : これらの会社はどのような印象を あなたに与えますか。

質問 2 : そのような印象をあなたに与える 要因は何ですか。

試験者 3 名は, 一つの部屋に 3 つの机を並べて, 被験者との個別面接による聞き取り調査を並行して 行い, 一名あたりの面接時間は約30分であった。

なお，Fig. 1に示した事務所内装写真20枚は，日 本国内で発行された雑誌に公開されたものを用い た。写真 P02, 07, 10, 11, 12, 14, 15, および17は木質 内装で，同じく $\mathrm{P} 01,03,04,05,06,08,09,13,16,18$, 19, および20は非木質内装である。

\section{3 テキスト型データの計量的分析}

聞き取り調査で得られたデータは，Table 1 に例 示したような表形式でまとめた。この回答例では, 被験者 1 番は写真を 6 つのグループに分けている。 さらに，被験者はグループごとに会社の印象および そのような印象を持つ理由を口頭で答え, それらを 聞き取った回答が右側の 2 列に記されている。限ら れた時間内での面接調査では，即答に近いため不完 全な文章も含まれるほか, とくに制限を設けていな いのでグループごとに回答数は異なる。全データは, $\mathrm{PDF}$ ファイルで公開されている既報 ${ }^{15)}$ の中に収め られている。

このようなテキストデータを計量的に分析するた め, 社会調査の学術研究などで広く使われている KH Coder (制作者: 立命館大学, 樋口耕一准教授, フリーソフトウェア）桌）用いた。本研究では, KH Coder の解析機能の中で, 多次元尺度構成法を 選択し，非計量的多次元尺度構成法の Kruskal ${ }^{17)}$ の 方法によって，写真番号や抽出された語が多次元空 間に位置付けられる状況を検討した。その際，回答 から抽出された語の「木材 wood」に着目し，木質

Table 1. Some of the results of grouping the workplace interior photographs and interview responses.

\begin{tabular}{|c|c|c|c|c|}
\hline Participant & Group & Photo No. & $\begin{array}{l}\text { Question } 1: \text { What is your impression of } \\
\text { the companies in each group? }\end{array}$ & $\begin{array}{l}\text { Question 2: What gives you that } \\
\text { impression? }\end{array}$ \\
\hline \multirow[t]{6}{*}{1} & 1 & $1,6,8,20$ & $\begin{array}{l}\text { 1. The company is modern. } \\
\text { 2. The workers are busy. } \\
\text { 3. The workers are career-oriented } \\
\text { and work very hard. }\end{array}$ & $\begin{array}{l}\text { 1. The white walls and interior give a } \\
\text { cold image. } \\
\text { 2. The room is not separated by walls } \\
\text { but by partitions, and it is easy to } \\
\text { walk about, giving the image of } \\
\text { hard-working people. }\end{array}$ \\
\hline & 2 & $3,4,13$ & $\begin{array}{l}\text { 4. The company has a loose hierarchy. } \\
\text { 5. The workers are friends. } \\
\text { 6. The workers have good ideas. }\end{array}$ & $\begin{array}{l}\text { 3. The interior design with pillars gives } \\
\text { a cold image. }\end{array}$ \\
\hline & 3 & $2,7,14$ & $\begin{array}{l}\text { 7. The company is small and warm. } \\
\text { 8. The company has few workers. } \\
\text { 9. The workers are friends with each } \\
\text { other and united. }\end{array}$ & $\begin{array}{l}\text { 4. The color of the wood used for the } \\
\text { interior gives a warm image. } \\
\text { 5. The color of the wood affects the } \\
\text { image of the workers. }\end{array}$ \\
\hline & 4 & 5,10 & $\begin{array}{l}\text { 10. The company is stiff (very formal). } \\
\text { 11. The company is large. } \\
\text { 12. The workers are the president or } \\
\text { executives (i.e., the office is occu- } \\
\text { pied by these people). }\end{array}$ & $\begin{array}{l}\text { 6. The dark brown color of the walls } \\
\text { and the interior gives a heavy im- } \\
\text { age. } \\
\text { 7. The image is like a president's room. }\end{array}$ \\
\hline & 5 & $\begin{array}{l}11,12,15 \\
17\end{array}$ & $\begin{array}{l}\text { 13. The company is warm. } \\
\text { 14. The company has few workers. } \\
\text { 15. The workers are friends and } \\
\text { united. }\end{array}$ & $\begin{array}{l}\text { 8. The light brown color of the interior } \\
\text { gives a warm image. }\end{array}$ \\
\hline & 6 & $\begin{array}{l}9,16,18 \\
19\end{array}$ & $\begin{array}{l}\text { 16. The company is calm (i.e., peaceful, } \\
\text { mild). } \\
\text { 17. The workers distinguish working } \\
\text { hours from nonworking hours. }\end{array}$ & $\begin{array}{l}\text { 9. The resting space gives a comfort- } \\
\text { able image. } \\
\text { 10. The sofas and plants of the interior } \\
\text { give the image that the workers are } \\
\text { calm. }\end{array}$ \\
\hline
\end{tabular}

Note: This table appeared in its entirety in reference No. 15. 
内装の視覚的影響を評価した。ここで, 多次元尺度 構成法とは,「データの中に潜む構造を探り出し, その構造を少数の次元の空間において幾何学的に表 現する」18) 方法である。非計量的多次元尺度構成法 では，「順序尺度で測定された類似性デー夕を入力 データとし，出力として空間配置を定める。」吕）そ のうち, Kruskal の方法では,「類似度と対象間の 距離とが単調関係となるように，対象を点として多 次元空間に位置付けることで，対象間の関係を表現 する。つまり, 多次元空間内に, 類似度の大きい対 象同士はそれぞれの対象を表現する点間の距離が小 さくなるように，類似度の小さい対象同士はそれぞ れの対象を表現する点間の距離が大きくなるよう に, 各対象の点を位置付ける。」 $\rfloor^{199}$

KH Coder のデータ処理の過程は，以下の通りで ある。テキストデー夕の準備段階で, 被験者ごとに グループに分けられた写真番号とそれに対応する二 つの質問に対する回答を一つの文書として扱えるよ うに区切りを設定する。例えば, Table 1 で示すと,

Photo No. 1，6，8，20, Question 1 に対する 3 つ の回答, 抢よび Question 2 に対する 2 つの回答 を1つの文書として扱う。KH Coder は，このよう に区切られた文書の集まりとしてテキストデータを 読み込み, 品詞ごとに分類して語を抽出し, 文書ご とに抽出された語の出現数を整理する。抽出された 語 $i$ と語 $j$ の類似度 $\delta_{i j}$ は, Jaccard 係数 $S_{j}$ によって 表される。すなわち，文書ごとに語 $i$ あるいは語 $j$ の出現数が 1 以上であれば 1 , 出現数が 0 であれ ば 0 をそれぞれ割り当てる。語 $i$ と語 $j$ が両方と も 1 の個数を $n_{11}$, 語 $i$ が 1 で語 $j$ が 0 の個数を $n_{10}$, 語 $i$ が 0 で語 $j$ が 1 の個数を $n_{01}$ とすると,

$$
\delta_{i j}=S_{J}=\frac{n_{11}}{n_{11}+n_{10}+n_{01}}
$$

語 $i$ と語 $j$ の距離 $d_{i j}$ は, 次式で表される。

$$
d_{\mathrm{ij}}=1-\delta_{i j}=\frac{n_{10}+n_{01}}{n_{11}+n_{10}+n_{01}}
$$

KH Coderでは，この $d_{i j}$ を初期值とし，プログ ラム言語 Rの isoMDS 関数 ${ }^{20}$ を利用して, 抽出さ れた語の多次元空間における配置を定めている。

\section{3. 結果と考察}

\section{1 事務所の内装写真の類似度に及ぼす「木材 wood」の影響 \\ グループに分けられた写真とそれに対応する二つ}

の質問に対する回答の全デー夕について, KH
Coder の非計量的多次元尺度構成法による解析機能 を用いて処理した結果を Fig. 2 に示す。木質内装の 写真 P $02,07,10,11,12,14,15$ 拈よび17（以下，木質 内装写真群）が図の右よりに位置付けられ，非木質 内装の写真 P01, 03, 04, 05, 06, 08, 09, 13, 16, 18, 19 および20（以下，非木質内装写真群）が図の左より に位置付けられていることが見て取れる。また，木 質内装写真群は「木材 wood」の近くに位置付けら れている。被験者には提示した20枚の写真に木質と 非木質の内装が含まれることを説明していないにも 関わらず， 2 次元空間に木質内装写真群と非木質内 装写真群が分かれて位置付けられる結果となった。

このような傾向をさらに検討するため, 全テキス トデータを, 回答に「木材 wood」を使った被験者 Participant 01, 02, 03, 05, 08, 09, 10, 12, 14, 15, 16, $17,18,19,20,21,22,23,24,25,26$ お よび28の 22 名 (以下,「木材 wood」被験者群) と, 回答に「木材 wood」を使わなかった被験者 Participant 04, 06, 07, 11，13および27の 6 名（以下，非「木材 wood」 被験者群）に分けて, 非計量的多次元尺度構成法に よる解析を行った結果をそれぞれ Fig. 3 と Fig. 4 に 示す。「木材 wood」被験者群 (Fig. 3) では, Fig. 2 に示した全テキストデータの解析結果とほぼ同 様, 木質内装写真群と非木質内装写真群が分かれて 位置付けられ，木質内装写真群は，「木材 wood」 の近くに位置付けられている。なお, Fig. 2 と Fig. 3 を比較すると, 布置語数の設定によって, 語の配 置は相対的に変化するので, 上下と左右は反転して いる。一方, 非「木材 wood」被験者群 (Fig. 4) では，木質内装写真群と非木質内装写真群が混在し ていることから, 非「木材 wood」被験者群は木質 内装と非木質内装を区別していないと推察される。 以上のことから, Fig. 2 に示した全テキストデー夕 の解析結果には, 全被験者 28 名中 22 名を占める「木 材 wood」被験者群の回答傾向が大きく影響してい ることが明らかになった。

\section{2 事務所の木質内装写真から受ける視覚的影響}

全被験者（Fig. 2) およびそれに大きく影響を及 ぼす「木材 wood」被験者群 (Fig. 3) の解析結果 の共通点として, 以下のことが指摘できる。すなわ ち, 木質内装写真群が「木材 wood」の比較的近く に位置付けられ，その周辺に「あたたかい warm $」$, 「快適 comfortable」,「静か calm」,「明るい bright」,「友好的 friendly」など, 良好な事務所環 境あるいはその会社や社員に対する好印象につなが る語が位置付けられていることから，木質内装写真 が視覚的に好ましい印象を与えると考えられる。こ 


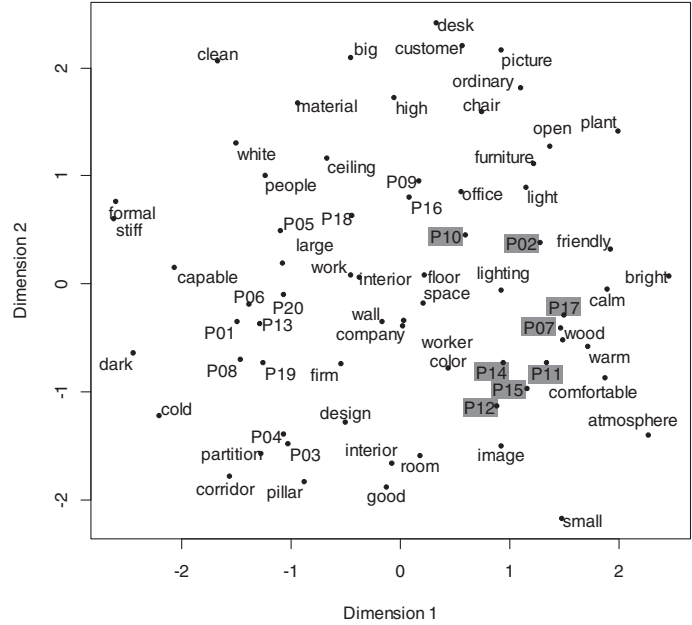

Fig. 2. Two-dimensional plot of the entire text data generated by nonmetric multidimensional scaling analysis.

Note: P01-20 refer to numbered photographs. Shaded numbers indicate photographs of wood workplace interiors.

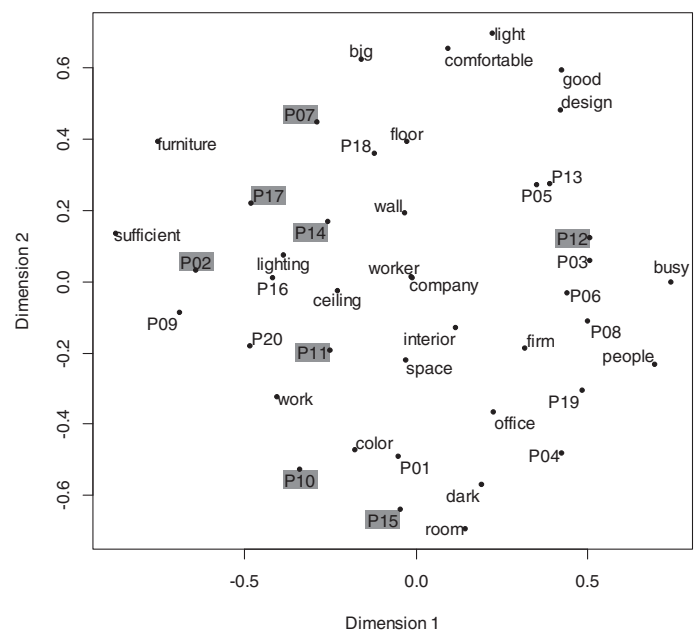

Fig. 4. Two-dimensional plot of the text data without "wood" generated by nonmetric multidimensional scaling analysis.

Note: The same as in Fig. 2.

の結果は，事務所の木質内装が木材に関心を示す 人々に対して好ましい視覚的影響を与える可能性が あることを示唆している。

緒言で述べた通り，視覚による「あたたかい」印 象については, 内装に現れている木材の色相や木材 量との関わりが深いことが明らかにされている ${ }^{3.4)}$ 。 本研究では, 被験者に対してグループに分けさせた 事務所内装写真から受ける印象について，二つの質

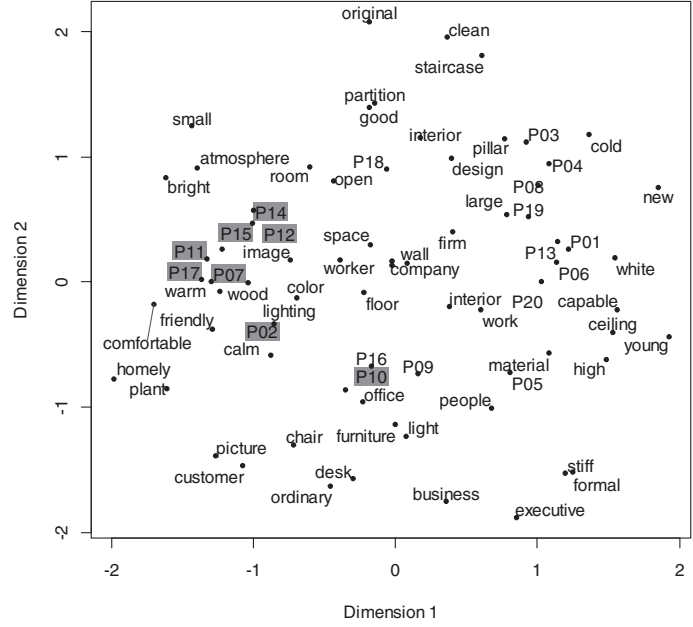

Fig. 3. Two-dimensional plot of the text data with "wood" generated by nonmetric multidimensional scaling analysis.

Note: The same as in Fig. 2.

問で自由に回答を求めたにもかかわらず，Fig. 2 と Fig. 3 に示すように, 回答の中から抽出された語の 「木材 wood」と「あたたかい warm」の近くに木 質内装写真群が位置付けられた。また, 事務所の内 装に関する先行研究 ${ }^{12,13)}$ では，木質内装はその職 場や使用者に対して好印象を持たせる効果があるこ とが明らかにされている。本研究では, Fig. 2 と Fig. 3 に示すように, 木質内装写真群が「木材 wood」の比較的近くに位置付けられ, その周辺に 良好な事務所環境あるいはその会社や社員に対する 好印象につながる語が位置付けられた。本研究では, これらの先行研究と実験方法などが異なるにもかか わらず，いずれの先行研究とも矛盾しない結果が得 られた。このことは，人間との係わりにおいて木材 が持つ普遍的な特性が反映している可能性を示すも のである。

\section{4. 結 論}

被験者には，提示した写真に木質と非木質の内装 が含まれることを説明していないにも関わらず，木 質内装写真群と非木質内装写真群が 2 次元空間に分 かれて位置付けられ，木質内装写真群は「木材 wood」の近くに位置付けられた。この「木材 wood」の周辺に,「あたたかいwarm」,「快適 comfortable」,「静か calm」,「明るい bright」,「友 好的 friendly」など，良好な事務所環境あるいはそ の会社や社員に対する好印象につながる語が位置付 けられた。この結果には, 回答に「木材 wood」を 
使った被験者群の回答傾向が大きく影響しているこ とが明らかになった。以上のことから，事務所の木 質内装が人々に好ましい視覚的影響を及ぼすことが 示唆された。

\section{謝辞}

本研究は, Dr. Bradley G. Ridoutt (Former Leader, Built Environment Programme, Forest Research, New Zealand）との共同研究の一環として行った。 宮崎良文博士（元森林総合研究所）には面接調査の 準備から実施まで分担していただき，半田 高博士 (元筑波大学) には被験者や調査場所の確保にご尽 力いただいた。中山厚穂博士 (首都大学東京)には, プログラム言語 $\mathrm{R}$ の多次元尺度構成法に関する関 数について，私信でご教示いただいた。ここに記し て謝意を表する。

\section{文献}

1）石川淳二：第 1 章産業における教育訓練と教 育機器. “産業教育機器システム便覧”, 教育機 器編集委員会編, 日科技連出版社, 東京, 1972, p. 4.

2）仲村匡司 : 木材の見えと木質内装. 木材学会誌 58(1), 1-10 (2012).

3）増田 稔, 山本尚美 : 室内空間における木材率 とイメージ. 京都大学農学部演習林報告 60 , 285-298 (1988).

4）増田 稔, 仲村匡司：室内空間における木材率 とイメージ(第 2 報). 京都大学農学部演習林 報告 62, 297-303 (1990)。

5）仲村匡司, 増田 稔：住宅内装画像における木 材領域の自動抽出 (第 2 報) 主観的木材率およ び学生居室の木材率. 木材学会誌 46(6), 566572 (2000).

6）仲村匡司, 増田 稔：住宅内装における木質部 材の存在形態と量が心理的イメージに与える 影響. 木材学会誌 50(6), 376-383 (2004).

7）平間昭光, 澤田哲則, 朝倉靖弘, 佐藤義明, 長谷 川優：人工照明下でのカラマツ内装材の視覚 効果. 北海道林産試験場報 18(2), 1-7 (2004).

8) Sakuragawa, S., Miyazaki, Y., Kaneko, T., Makita, T. : Influence of wood wall panels on physiological and psychological responses. $J$. Wood Sci. 51 (2), 136-140 (2005).

9) Tsunetsugu, Y., Miyazaki, Y., Sato, H.: The visual effects of wooden interiors in actualsize living rooms on the autonomic nervous activities. J. Physiol. Anthropol. Applied Human Sci. 21 (6), 297-300 (2002).

10) Tsunetsugu, Y., Sato, H., Miyazaki, Y.: Visual effects of interior design in actual-size living rooms on physiological responses. Building and Environment 40 (10), 1341-1346 (2005).

11) Tsunetsugu, Y., Miyazaki, Y., Sato, H. : Physiological effects in humans induced by the visual stimulation of room interiors with different wood quantities. J. Wood Sci. 53(1), 11-16 (2007).

12) Ridoutt, B. G., Ball, R. D., Killerby, S. K. : Wood in the interior office environment: Effects on interpersonal perception. For. Prod. J. 52(9), 23-30 (2002).

13) Ridoutt, B. G., Ball, R. D., Killerby, S. K. : First impressions of organizations and the qualities connoted by wood in interior design. For. Prod. J. 52(10), 30-36 (2002).

14) Ridoutt, B. G., Sueyoshi, S., Ball, R. D., Miyazaki, Y., Morikawa, T.: Homeowner identity symbolism in Japanese housing constructions. For. Prod. J. 55(4), 31-37 (2005).

15）末吉修三, 森川 岳：事務所の内装に使われた 木材によってもたらされる視覚的影響 - 聞き 取り調査一。森林総合研究所研究報告 $14(2)$, 77-123 (2015).

16）樋口耕一：資料A KH Coder リファレンス・ マニュアル。“社会調査のための計量テキスト 分析 - 内容分析の継承と発展を目指して - ”, ナカニシヤ出版, 京都, 2014, pp. 101-201.

17) Kruskal, J. B. : Multidimensional scaling by optimizing goodness of fit to a nonmetric hypothesis. Psychometrika 29(1), 1-27 (1964).

18）齋藤堯幸 : 5 . 非計量的多次元尺度構成法（単 相 2 元デー夕). “多次元尺度構成法”, 朝倉書 店, 東京, 1980, p. 72 .

19）中山厚穂, 横山 暁：「MDSを使って使って使 い倒す！MDS入門から非対称MDS実習ま で」. 日本行動計量学会 第13回春の合宿セミナ 一資料, 御殿場, 2010, pp. 1-18.

20) R Documentation: Kruskal's non-metric multidimensional scaling, isoMDS http://finzi.psych.upenn.edu/R/library/ MASS/html/isoMDS.html 2016年 6 月14日参照. 